\title{
The Effects of Defoliation by the Larch Casebearer on the Radial Growth of Tamarack
}

\author{
by
}

Paul Benoit and Robert Blais ${ }^{1}$

\begin{abstract}
Tamarack (Larix laricina [DuRoi] K. Koch) was severely defoliated by the larch casebearer (Coleophora laricella) in most areas of Quebec during 1979 and 1980. Increment core samples were taken in late September 1982 from 20 tamaracks in each of two stands to determine the effect of defoliation on radial growth. In one stand, the trees were $80 \%$ defoliated in 1980 and during this year radial growth was reduced by $52 \%$. Growth returned to predefoliation level the following year when the trees were not defoliated. In the other stand, trees were $60 \%$ defoliated in 1979 and $70 \%$ in 1980 . During these years, radial growth was reduced by 48 and $70 \%$ respectively. Growth in this stand had not fully returned to predefoliation level two years after the collapse of the infestation. In both stands, variations in defoliation among trees did not exceed $10 \%$ of the average.
\end{abstract}

Key Words: Coleophora laricella, larch casebearer, tamarack, larch, defoliation.

\begin{abstract}
Résumé
Dans le but de mesurer l'effet du défeuillement par le porte-case du mélèze (Coleophora laricella) sur le mélèze laricin (Larix laricina [DuRoi] K. Koch), nous avons étudié deux peuplements situés dans la région au nord de Montréal et défeuillés, l'un en 1980 et l'autre en 1979 et 1980. En 1982, nous avons mesuré la croissance radiale annuelle au dhp des dix années antérieures à l'infestation, et durant et après cette dernière. Des bàtonnets de croissance furent extraits de vingt arbres par peuplement et les mesures des cernes annuels furent effectuées en laboratoire. Les résultats démontrent que: 1) dans le premier peuplement où une seule année de défeuillement ( $80 \%$ du feuillage détruit) fut observée, les pertes de croissance radiale s'élevèrent à $52 \%$ au cours de cette année et qu'en l'absence de l'insecte durant l'année suivant, la croissance revint à la normale prédéfeuillement; 2) dans le second peuplement, la croissance radiale fut réduite de 48 et $70 \%$ au cours des deux années de défeuillement (à 60 et $70 \%$ ), respectivement. Après la chute de l'infestation, la croissance ne fut que de 50 et $70 \%$ respectivement pour les années 1981 et 1982 . En supposant une croissance normale en 1983, laquelle ne fut pas vérifiée, le total minimum des pertes dues à cette infestation équivalait à deux années de la moyenne de croissance obtenue pour la période prédéfeuillement.
\end{abstract}

Mots clés: Coleophora laricella, porte-case du mélèze, mélèze laricin, défeuillement.

\section{Introduction}

The larch casebearer, Coleophora laricella ( $\mathrm{Hbn}$.) (Lepidoptera: Coleophoridae), is a European pest which was found for the first time on the North American continent in Massachussetts in 1886. It now occurs in the east on both sides of the Canada-US border from Newfoundland to central Wisconsin and southeastern Manitoba.

West of the Rockies, the distribution of the insect covers the panhandle of Idaho, northeastern Washington, north-

Laurentian Forestry Centre, Canadian Forestry Service, 1055, du P.E.P.S.. P.O. Box 3800, Sainte-Foy, Quebec G1V 4C7. The first author retired in December 1986. western Montana and in the bordering areas in southeastern British Columbia (Martineau 1985; Webb and Denton 1967). The larch casebearer is second only to the larch sawfly, Pristiphora erichsonii ( $\mathrm{Htg}$.), as the most serious defoliator of both native and exotic species of larch in North America (Martineau 1985; Webb and Denton 1967).

Larch casebearers are tiny moths that are active all summer. Eggs are laid on the needles in late June and hatching occurs in two weeks. Larvae mine the needles until late summer. Then, the larva chews the needle off the twig. The needle is used as a portable shelter for the rest of its larval life. In feeding, the larva attaches repeatedly the fore-end of the case to each new needle it mines. Winter is spent in the case which is fastened with silk, usually at the base of a bud. 
Feeding is resumed in the spring and new needles are mined for about a month. When the insect larva outgrows its case, it makes a new one. Pupation occurs in the case and a new moth emerges about two to three weeks later.

The greatest damage occurs during the second year of feeding. If the tree is completely stripped of its foliage, it usually refoliates during the current summer. Because a severe defoliation by larch casebearer completely defoliates a tree, its impact on the radial growth of larch is greater than that of a severe spruce budworm defoliation on the radial growth of balsam fir and spruce where usually only the new foliage is eaten. However, the casebearer is a less serious pest than the hemlock looper which completes its life cycle and destroys most of the foliage of balsam fir in one season. Balsam fir does not refoliate.

To date, no mortality of larch over large tracts has occurred due to the larch casebearer, but growth has often been reduced. Tunnock et al. (1969) have documented such an example and Kulman (1971) has reported cases of artificial defoliation and natural defoliation by different insects. The casebearer also weakens the trees, making them susceptible to other causes of mortality. Fortunately, parasitoids imported from Europe decades ago and predators are believed to bring about the rapid collapse of outbreaks in many cases (Webb and Denton 1967).

In 1979 and 1980, a moderate to severe infestation of the casebearer spread to most larch stands in southcentral Quebec (Lachance et al. 1980, 1981). The insect population collapsed in 1981 (Benoit et al. 1982). In 1982, two stands of tamarack, close to Sainte-Marguerite, north of Montreal, were sampled to determine the effect of this defoliator on the growth of the trees.

\section{Methods}

Both selected stands were mixed. They were composed of: $70 \%$ tamarack, $10 \%$ balsam fir (Abies balsamea [L.] Mill.), $10 \%$ black spruce (Picea mariana [Mill.] B.S.P.), and $10 \%$ eastern white cedar (Thuja occidentalis L.). Defoliation (by its browning effect) was measured from the ground by experienced rangers whose visual estimations were checked with a few branch samples to avoid over or underestimation of defoliation. No subsequent visits to the stands were made to observe whether or not refoliation of tamarack had occurred. However, it rarely fails to do so with healthy trees.

At the end of September 1982, one increment core was taken at breast height from each of the 20 trees of tamarack and eastern white cedar, along a 200-m line within each of the two stands studied. Eastern white cedar was chosen as a control because it had no recent history of insect or disease infestations in the region and its growth was related mainly to climate and to site conditions in the stands.

The tamaracks sampled in stand $A$ (one year of defoliation), ranged from 11.7 to $22.1 \mathrm{~cm} \mathrm{DBH}(\bar{X}=15.7 \mathrm{~cm})$; from 16.8 to $24.4 \mathrm{~m}$ high $(\bar{X}=21 \mathrm{~m})$; and from 74 to 86 years old $(\bar{X}=81 \mathrm{y}$.). For eastern white cedar, the average respective measurements were $19.1 \mathrm{~cm} \mathrm{DBH}, 11.7 \mathrm{~m}$ high and 73 years old (49 to 84 y.).

In stand $\mathrm{B}$ (two years of defoliation) the tamarack were 10.8 to $28.6 \mathrm{~cm}$ DBH $(\bar{X}=19.9 \mathrm{~cm}) ; 9.1$ to $21.3 \mathrm{~m}$ high $(\bar{X}=$ $15.9 \mathrm{~m})$; and from 50 to 90 years old $(\bar{X}=75 \mathrm{y}$.). For eastern white cedar, the averages were $15.8 \mathrm{~cm} \mathrm{DBH}, 8.6 \mathrm{~m}$ high and
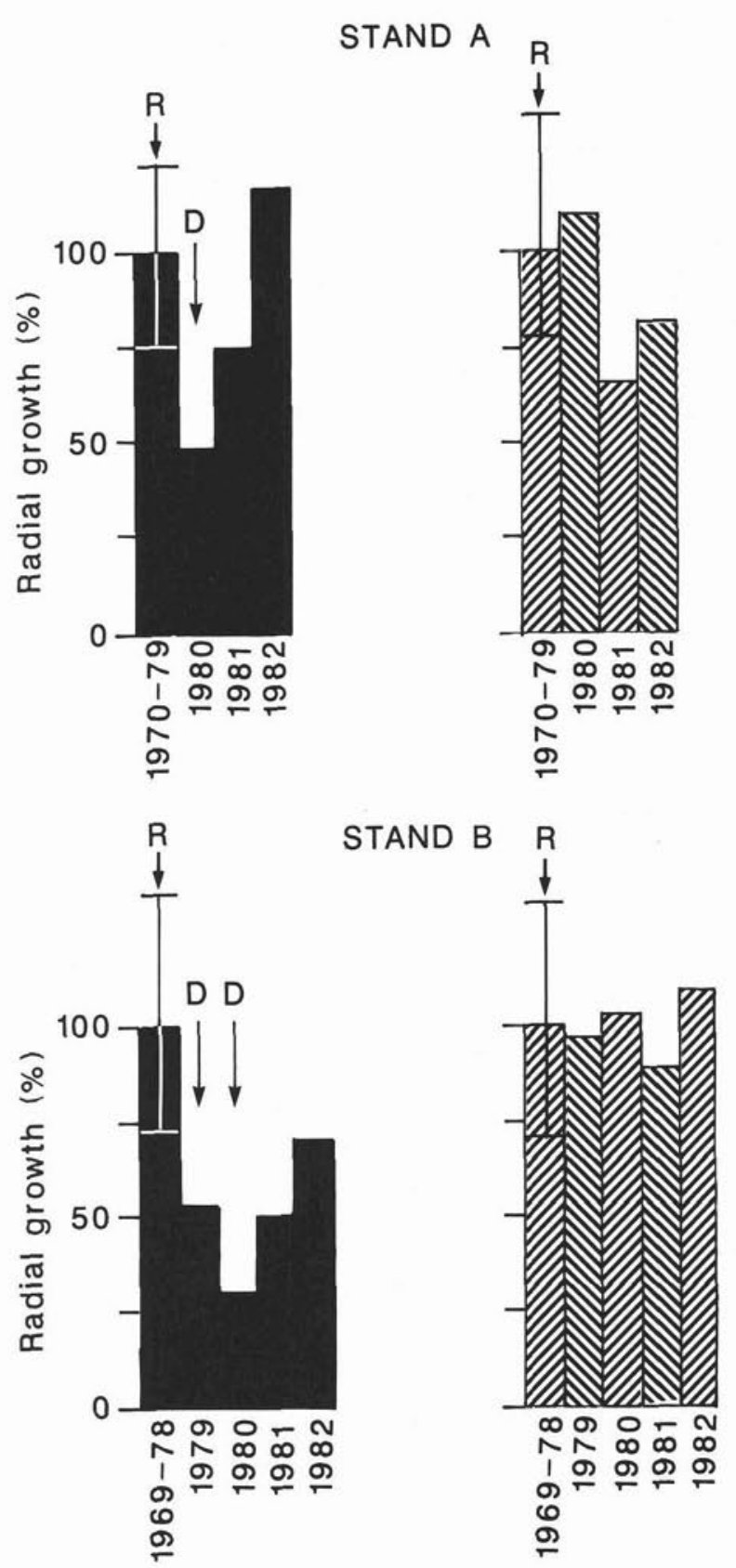

Years

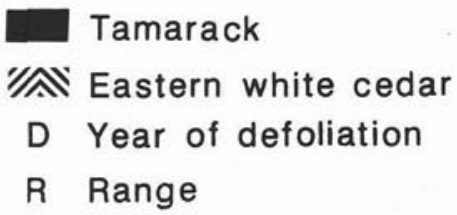

Figure 1. Effect of defoliation by larch casebearer on radial growth of tamarack and recovery at the end of infestation. Eastern white cedar was used as control.

82 years old (63 to $98 \mathrm{y}$.). The sampled trees of both tree species were representative of the whole stands. Both stands were about 1 ha and basal area was $23 \mathrm{~m}^{2} / \mathrm{ha}$, measured with a wedge prism. 
With a low power (15-30X) microscope equipped with a micrometer, radial growth was measured: 1) for the 10-year period prior to infestation in each stand, to estimate the normal growth rate of the trees; 2) during the period of infestation (1979 and 1980), to determine the effect of defoliation on radial growth; and 3) during the two years (1981-1982) following the collapse of the larch casebearer infestation, to estimate the growth recovery.

\section{Results}

Tamarack in stand A (Fig. 1) was $80 \%$ defoliated in 1980 and showed a $52 \%$ reduction of average radial growth for that year compared with the previous 10-year average growth. Growth of tamarack in 1981 was comparable to that of cedar, both were only $65-75 \%$ of the $1970-79$ average. In 1982 , radial growth for tamarack was $15 \%$ more than the $1970-79$ average value while cedar was $18 \%$ less.

In stand B (Fig. 1), tamarack was $60 \%$ defoliated in 1979 and $70 \%$ in 1980 , with a reduction of annual growth of $48 \%$ in the first year and $70 \%$ during the second year of defoliation compared with the 1969-78 average. After defoliation ceased, growth increased to $50 \%$ of the $1969-78$ rate during the first year and to $72 \%$ during the second year. Growth would probably have been near the predefoliation average during the third year, but the study was not pursued to determine this assumption. In comparison, during the period 1979 to 1982 , growth of cedar ranged from $16 \%$ below to $15 \%$ above the 1969-78 average.

\section{Conclusions}

Larch could become an important source of fibre in the future. The 50 to $70 \%$ reduction of tamarack radial growth by the larch casebearer defoliation found in this study suggests that managers will have to consider protection measures.
Moreover, the effect of such a short but drastic stress could make the trees more susceptible and sometimes more vulnerable to attacks by another insect, the eastern larch beetle (Dendroctonus simplex Lec.), which can bring rapid death to stressed trees (Lachance et al., 1984).

\section{Acknowledgments}

We thank Dr. D.A. MacLean, Canadian Forestry Service (CFS)Maritimes and Dr. C.J. Sanders, CFS-Great Lakes Forestry Centre for reviewing the manuscript. Their comments and suggestions improved the presentation and contents of this article. We also extend our appreciation to Mrs. J. Murphy for her editorial assistance.

\section{References}

Benoit, P., G. Bonneau, G. Laflame and R. Picher. 1982. Insectes et maladies des arbres-Québec 1981. Suppl. in For. Conserv. 48(10), $20 \mathrm{p}$.

Kulman, H.M. 1971. Effects of insect defoliation on growth and mortality of trees. Am. Rev. Ent. 16: 289-324.

Lachance, D., P. Benoit, G. Bonneau et G. Laflamme. 1980. Insectes et maladies des arbres-Québec 1979. Suppl. in For. Conserv. 46(10), $24 \mathrm{p}$.

Lachance, D., P. Benoit, G. Bonneau and G. Laflamme. 1981. Insectes et maladies des arbres-Québec 1980. Suppl. in For. Conserv. 47(9), $20 \mathrm{p}$.

Lachance, D., P. Benoit, G. Bonneau and R. Picher. 1984. Insectes et maladies des arbres-Quèbec 1983. Suppl. in For. Conserv. $50(10), 26 p$.

Martineau, R. 1985. Insects Harmful to Forest Trees. Multiscience Publications Ltd. and Can. For. Serv. Ottawa, Ontario, $261 \mathrm{p}$.

Tunnock, S., R.E. Denton, C.E. Carlson and W.W. Jannsen. 1969. Larch casebearer and other factors involved with deterioration of western larch stands in Northern Idaho. USDA For. Serv. Res. Paper INT-68. 10 p.

Webb, F.E. and R.E. Denton. 1967. Larch casebearer, Coleophora laricella ( $\mathrm{Hbn}$.), in Important Forest Insects and Diseases of Mutual Concern to Canada, the United States and Mexico. Can. Dept. For. Rural Dev., Ottawa, Canada. p. 85-88, (illus. p. 84).

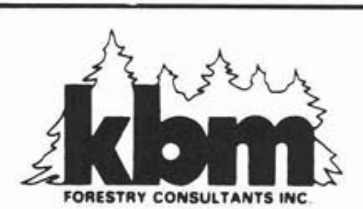

360 mooney street

thunder bay, ontario P7B 5R4

$$
\begin{gathered}
\text { REFORESTATION EQUIPMENT } \\
\text { - Sales Service Parts Repair }
\end{gathered}
$$

REGENERATION \& SITE PREPARATION

- Contract Assessment Consulting

807-344-0811 telex 073-4603

\section{EDWARD \\ S. \\ FELLOWS \\ MEMBER: \\ Canadian Institute of Forestry \\ Forest Products Research Society \\ etc. \\ FORESTRY \& FOREST PRODUCTS CONSULTANT}

Mall address:

P.O. BOX 354 ,

Phone: (506) 455-3232

INDUSTRY DEVELOPMENT - FOREST PRODUCTS FOREST ECONOMICS, POLICY AND ADMINISTRATION 